\title{
Interventional catheterization for congenital heart defects: what can we do for others? Project Rwanda
}

\author{
Jacek Białkowski \\ Department of Congenital Heart Defects and Paediatric Cardiology, Medical University of Silesia, Silesian Centre for Heart Diseases, Zabrze, \\ Poland
}

Adv Interv Cardiol 2019; 15, 3 (57): 385-386 DOI: https://doi.org/10.5114/aic.2019.87903

Interventional catheterization has nowadays become the method of choice in treatment of several congenital heart defects (CHD). It is also developing quickly in Poland. The number of transcatheter procedures reached a similar number to cardiac surgery procedures in CHD in 2018 (2293 vs. 2271) [1]. Our interest in international collaboration and development of interventional cardiology in CHD has been evolving for many years. Recently, we were awarded by the Polish Cardiac Society for 24 articles published in the years 2012-2017 [2]. In 2007 we started in our centre an educational programme for young interventional CHD cardiologists from different countries. Since then, we have trained 23 cardiologists (all below 40 years old) from different countries in Europe (Ukraine, Belarus, Bulgaria, Georgia, Italy, Russia), Latin America (Mexico, Colombia, Bolivia, Guatemala, Argentina), Asia (Uzbekistan, China) and Africa (Rwanda). The training period varied from 1 to 12 months.

A Letter to the Editor titled 'Percutaneous treatment of CHD, what was new in 2014' was recently published in Kardiologia Polska [3], describing, among other topics, my idea of a mobile cath-lab laboratory mounted on a truck for Africa needs. Despite the fact that we received support from a key person of the World Health Organization (WHO) and the Vatican, unfortunately, the latter project has not developed further. Also interest showed by African paediatric cardiologists in this idea (presented by me) during the CSI Africa Congress in Addis Ababa in December 2014 and the CSI in Frankfurt (main congress) in June 2015 was moderate. I have started to think that something is wrong and that the idea might be too general and I should change the strategy [4]. The next step was my "tourist" visit to Rwanda in 2018 and fellowship of Dr Yves Mutabandama in 2019 in our centre
(Silesian Centre for Heart Diseases, Zabrze). He is well educated, finishing his paediatric cardiology training at Kigali Teaching University in Rwanda. Rwanda is a small African, equatorial country. It has only 26000 square km and a population of 12.5 million habitants (60\% children) with a stormy contemporary history. However, now it has become a politically and economically stable country. As in many other Central and Eastern Africa countries, there are no regular cardiac catheterizations laboratories. In Rwanda some simples percutaneous interventions in CHD were performed only during a few missions organized by a charity organization from Europe (the Chain of Hope, Belgium) with an X-ray C arm [5]. As we discussed with Dr Joseph Mucumbitsi (an experienced cardiologist) during my visit to Rwanda in 2018 and Dr Mutabandama, the need to organize a permanent cath lab in Rwanda, not only for treatment of CHD patients, but also for adult coronary artery disease procedures, is fundamental. It is a big project that will need strong support from many institutions, especially the Rwanda Ministry of Health. Economic support to build a cath lab and logistic support to educate all medical staff - nurses, technicians, medical doctors - will be needed. In my opinion, many international organizations such as WHO, charity foundations, European Society of Cardiology (ESC), and European Association of Percutaneous Cardiovascular Interventions (EAPCI) can do a lot in this field. There is also a place for Polish institutions such as PTK (Polskie Towarzystwo Kardiologiczne) and AISN (Asocjacja Interwencji Sercowo-Naczyniowych).

In conclusion, the idea of a mobile cath lab for Africa is not feasible. A more practical and useful strategy is to organize a fully equipped, traditional cath lab with financial, logistic and personal support.

\section{Corresponding author:}

Prof. Jacek Białkowski MD, PhD, Department of Congenital Heart Defects and Paediatric Cardiology, Medical University of Silesia, Silesian Centre for Heart Diseases, 9 M. Curie-Sklodowskiej St, 41-800 Zabrze, Poland, phone/fax: +48 32 271 34 01, e-mail: jabi_med@poczta.onet.pl Received: 16.07.2019, accepted: 9.08.2019. 


\section{Conflict of interest}

The author declares no conflict of interest.

\section{References}

1. Białkowski J, Szkutnik M, Powałka A. Interventional catheterization in pediatric catheterization laboratories for congenital and structural heart defects during 2009-2018 in Poland. Report of the National Consultant of Pediatric Cardiology. Adv Interv Cardiol 2019; 15: 374-6.

2. Białkowski J. Progress in the interventional treatment of congenital and structural heart defect - scientific award of the Polish Cardiac Society. Kardiol Pol 2018; 76: 68-9.

3. Bialkowki J. Interwencyjne leczenie wrodzonych i strukturalnych wad serca: co nowego w 2014 roku? Projekt mobilnej hemodynamiki dla krajów rozwijających się. Kardiol Pol 2015; 73: 69-71.

4. Bialkowski J. Mobile cathlab for the treatment of congenital heart defects - is it real idea? My own experience and example of Rwanda. Congenital Cardiol Today 2018; 16: 9-13.

5. Senega J, Rusingiza E, Mucumbitsi J, et al. Catheter interventions in congenital heart diseases without regular catheterization laboratory equipment: the Chain of Hope experience in Rwanda. Ped Cardiol 2013; 34: 39-45. 